\title{
The role of seroepidemiology in the comprehensive surveillance of vaccine-preventable diseases
}

\author{
Sarah E. Wilson MSc MD, Shelley L. Deeks MD MHSc, Todd F. Hatchette MD, Natasha S. Crowcroft MSc MD
}

Competing interests: The authors received funding from the Canadian Institutes of Health Research to host a meeting to discuss the establishment of a seroepidemiology network. No other competing interests were declared.

This article has been peer reviewed.

Correspondence to: Dr. Sarah E. Wilson, sarah.wilson@oahpp.ca

CMAJ 2012. DOI:10.1503 /cmaj.110506

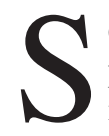
erological surveillance (serosurveillance) provides estimates of population-level immunity against vaccine-preventable diseases using cross-sectional studies of antibody prevalence. Seroepidemiology is important for evaluating the impact of vaccination programs, as these programs change the immunity of populations, both vaccinated and unvaccinated.

Seroepidemiology networks test sera from multiple jurisdictions to estimate age- and sexspecific seroprevalences for specific regions. Despite a strong evidence-based immunization policy, Canada does not have a seroepidemiology network to measure the impact of its vaccination programs. Evidence-informed vaccination policy is more important than ever when one considers the rising costs of new vaccines, waning immunity against select vaccine-preventable diseases, increasing numbers of new Canadians who may be susceptible to vaccine-preventable diseases and an aging population whose immune response following vaccination is less predictable.

The monitoring of vaccine-preventable disease in Canada currently consists of surveillance of reportable diseases, adverse events following immunization and immunization coverage. Notifications of reportable disease are important for monitoring trends and detecting outbreaks, but they are known to underestimate incidence and provide little information about the probability of

\footnotetext{
- KeY POINTS

- Despite strong supporting systems for the surveillance of vaccinepreventable diseases, Canada does not have a comprehensive approach to seroepidemiology.

- Serosurveillance provides estimates of population-level immunity against vaccine-preventable diseases using cross-sectional studies of antibody prevalence.

- The potential applications of seroepidemiologic data include estimating the burden of specific vaccine-preventable diseases, predicting potential outbreaks, identifying groups at risk and evaluating the impact of vaccination programs.

- Owing to Canada's range of immunization schedules, its diverse and growing population of new Canadians and its history of evidencebased immunization policy, the country would benefit from a seroepidemiology network.
}

future outbreaks. ${ }^{2}$ When combined with mathematical modeling, seroepidemiologic data can show the gradual accumulation of susceptible people, changes in the age-specific risk of infection and the potential for outbreaks. This data can be used to evaluate the impact of vaccination programs and inform decisions concerning vaccine policy, including establishing "catch-up" vaccination programs to help mitigate the risk of outbreaks.

National serosurveillance programs are wellestablished in many countries (Table 1). ${ }^{1,3-15}$ The European seroepidemiology program coordinates serosurveillance across 18 European countries despite national differences in methods for serum collection, disease epidemiology and immunization schedules. Although the Canadian Health Measures Survey will examine the seroprevalence of viral hepatitis, ${ }^{16-18}$ a comprehensive approach to the seroepidemiology of vaccinepreventable diseases does not exist in Canada. This review describes the rationale for establishing a seroepidemiology network in Canada.

\section{Why seroepidemiology is important for Canada}

Canada has 13 distinct immunization programs that differ by province/territory, each of which has information systems of variable quality documenting vaccine coverage. In addition, the country's growing immigrant population challenges our ability to predict future outbreaks of vaccinepreventable disease, since current national data on immunization coverage are survey-based with small sample sizes and focus largely on childhood immunization. Since 2000, 50\% of the more than 250000 newcomers who enter Canada each year come from regions that have no vaccine program for rubella or mumps (Figures 1 and 2). ${ }^{19-23} \mathrm{~A}$ seroprevalence study involving adult immigrants and refugees in Montréal, Quebec, found that 36\% were nonimmune to at least one of measles, mumps or rubella (MMR). ${ }^{21}$ Aboriginal populations in Canada are another important group for whom susceptibility to vaccine-preventable dis- 
eases may differ from that of the general population, ${ }^{24,25}$ and for whom immunization coverage is challenging to ascertain.

\section{Applying seroepidemiology data}

\section{Estimating the burden of vaccine- preventable disease}

Understanding the burden of disease is critical in evaluating whether vaccines should be included in immunization programs. ${ }^{26}$ Seroepidemiologic data can help clarify trends in the burden of vaccine-preventable diseases where notifications may be incomplete or nonrepresentative. Investigators from the Netherlands found that serologic evidence of recent pertussis in people 9 years of age and older more than doubled over a 10-year period. This was consistent with data on notifications and admissions to hospital, suggesting that the increase in pertussis cannot be fully explained by improvements in diagnostics and reporting. ${ }^{27}$ Conversely, Australian investigators found serologic evidence of recent pertussis increased among adults between 1997-98 and 2002, despite a relatively low and stable rate of notification for the disease (Figure 3). ${ }^{28}$ Such evidence suggests that the burden of disease in this age group was underestimated.

\section{Understanding emerging infections}

Knowledge of age-specific immunity to emerging infections is important for modeling the future burden of disease, formulating vaccine policy and planning for health care resources. Seroprevalence studies done during the H1N1 influenza pandemic were important for identifying risk factors for infection, anticipating the size of the second wave, estimating the final burden of disease and modeling the effectiveness of public health interventions, such as school closures and vaccination. ${ }^{29-31}$

\section{Identifying at-risk groups}

Immigrants and refugees settling in Canada comprise a group at risk for certain vaccine-

Table 1: Examples of national seroepidemiology programs

\begin{tabular}{|c|c|c|c|c|}
\hline $\begin{array}{l}\text { Seroepidemiology } \\
\text { program }\end{array}$ & Australia ${ }^{4,6}$ & Netherlands $\mathrm{s}^{7,8}$ & United Kingdom ${ }^{9}$ & United States ${ }^{10,11}$ \\
\hline Year of implementation & 1997-99 & $1995 / 96$ & $1986 / 87$ & $1999 *$ \\
\hline Sampling strategy & Use of residual sera & $\begin{array}{l}\text { Population-based } \\
\text { random sampling }\end{array}$ & Use of residual sera & $\begin{array}{l}\text { Population-based } \\
\text { random sampling }\end{array}$ \\
\hline $\begin{array}{l}\text { Over-sampling of } \\
\text { specific groups }\end{array}$ & No & $\begin{array}{l}\text { Municipalities with low } \\
\text { immunization coverage }\end{array}$ & No & $\begin{array}{l}\text { Certain ethnic } \\
\text { groups (e.g., } \\
\text { Hispanic Americans) }\end{array}$ \\
\hline $\begin{array}{l}\text { Administration of a } \\
\text { questionnaire (e.g., } \\
\text { gathering information } \\
\text { on demographics, } \\
\text { immunization history) }\end{array}$ & No & Yes & No & Yes \\
\hline $\begin{array}{l}\text { Collection of physical } \\
\text { measures other than } \\
\text { sera (e.g., } \\
\text { anthropometry, blood } \\
\text { pressure) }\end{array}$ & No & No & No & Yes \\
\hline $\begin{array}{l}\text { Examples of vaccine- } \\
\text { preventable diseases } \\
\text { studied to date }\end{array}$ & $\begin{array}{l}\text { Measles; mumps; } \\
\text { rubella; varicella; } \\
\text { hepatitis A, B and C; } \\
\text { diphtheria; tetanus; } \\
\text { polio; pertussis; } \\
\text { meningococcal C; } \\
\text { cytomegalovirus; } \\
\text { Helicobacter pylori }\end{array}$ & $\begin{array}{l}\text { Measles; mumps; } \\
\text { rubella; varicella; } \\
\text { hepatitis A, B and C; } \\
\text { diphtheria; tetanus; } \\
\text { polio; pertussis; } \\
\text { Streptococcus } \\
\text { pneumoniae; human } \\
\text { papillomavirus }\end{array}$ & $\begin{array}{l}\text { Measles; mumps; rubella; } \\
\text { diphtheria; tetanus; varicella; } \\
\text { hepatitis A, B and C; herpes } \\
\text { simplex virus } 1 \text { and 2, parvovirus } \\
\text { B19; Norwalk virus; Helicobacter } \\
\text { pylori; Toxoplasma gondii; } \\
\text { meningococcal C }\end{array}$ & $\begin{array}{l}\text { Measles; varicella; } \\
\text { rubella; hepatitis } \\
\text { A, B,C and D; } \\
\text { herpes simplex } \\
\text { virus } 1 \text { and 2; } \\
\text { human } \\
\text { papillomavirus; } \\
\text { Helicobacter pylori; } \\
\text { Toxoplasma gondii }\end{array}$ \\
\hline $\begin{array}{l}\text { Example of vaccine } \\
\text { policy or other advances } \\
\text { influenced by program }\end{array}$ & $\begin{array}{l}\text { Targeting varicella } \\
\text { vaccination to } \\
\text { children under } 5 \text { years } \\
\text { of age }^{12}\end{array}$ & $\begin{array}{l}\text { Establishment of } \\
\text { multiplexing techniques } \\
\text { for testing large, } \\
\text { population-based } \\
\text { serum banks }{ }^{7}\end{array}$ & $\begin{array}{l}\text { Addition of meningococcal C } \\
\text { conjugate vaccine booster at } \\
12 \mathrm{mo}^{13}\end{array}$ & $\begin{array}{l}\text { Recommendations } \\
\text { for use of } \\
\text { quadrivalent } \\
\text { vaccine for human } \\
\text { papillomavirus }\end{array}$ \\
\hline
\end{tabular}




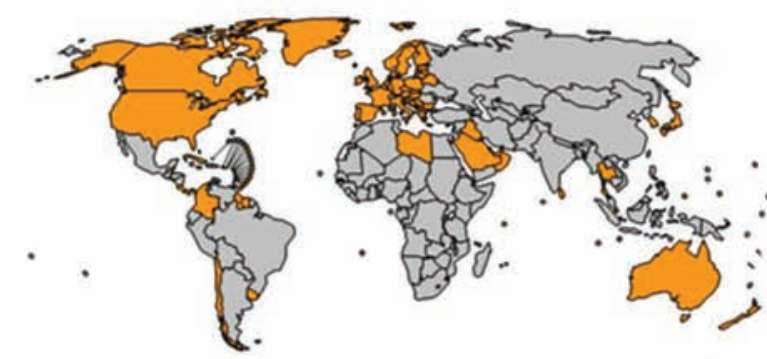

1996

83 countries

$13 \%$ of birth cohort

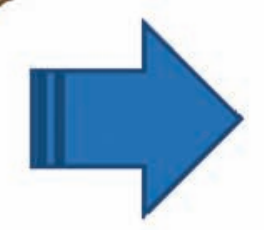

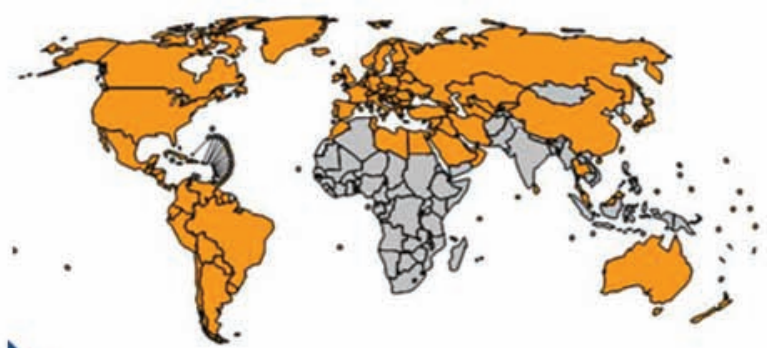

2008

127 countries

$40 \%$ of birth cohort

Rubella vaccination

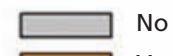

Yes

Figure 1: Countries using rubella vaccine in their national immunization schedules in 1996 and in 2008. ${ }^{22}$ From: www.who.int/immunization _monitoring/diseases/rubella_map_age.jpg (accessed 2011 Aug. 26). Reprinted with the permission of the World Health Organization.

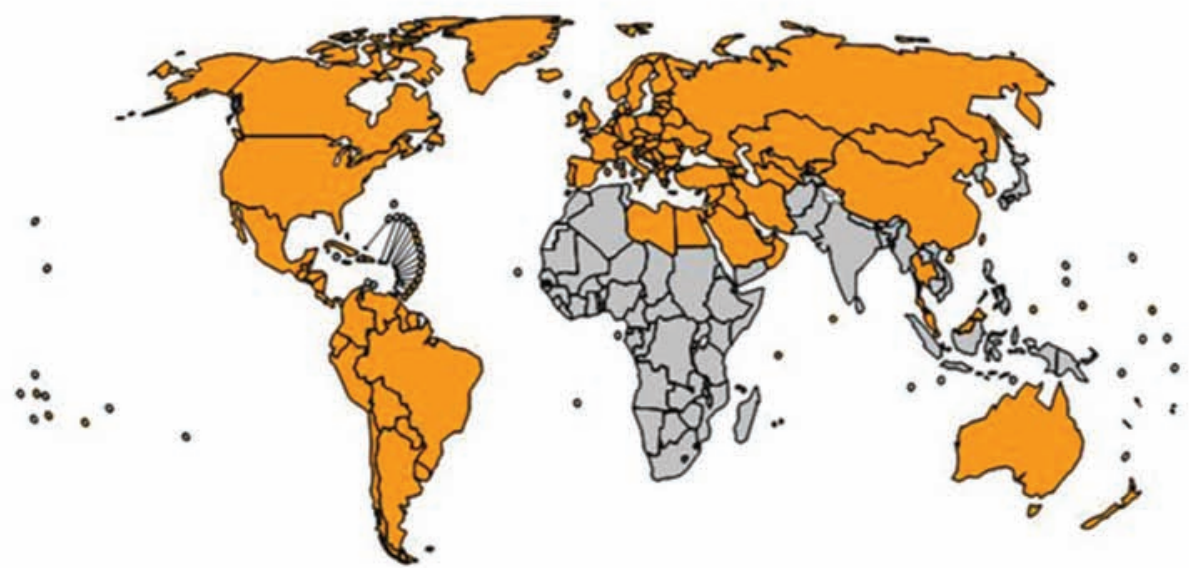

Mumps vaccination

$\square$ No (76 countries or $39 \%)$

Yes (117 countries or $61 \%)$

Source: WHO/IVB database, 193 WHO Member States. Data as of July 2010.

Date of slide: 19 August 2010.

Figure 2: Countries using mumps vaccine in their national immunization schedules in $2009 .^{23}$ From: www.who.int/immunization_monitoring /diseases/mumps_map_schedule.jpg (accessed 2011 Aug. 26). Reprinted with the permission of the World Health Organization. 
preventable diseases. Seroprevalence studies done in populations of immigrants and refugees in Montréal, Que., ${ }^{21}$ in Boston, Massachusetts, ${ }^{32}$ and in the United Kingdom ${ }^{33}$ have found substantial susceptibility to MMR and varicella consistent with both the variability in global vaccine recommendations and uptake and the epidemiology of natural infection outside of North America and western Europe. Outbreaks of rubella within migrant populations from Latin America have occurred in the United States and parts of Europe. ${ }^{3436}$ Since 1996, new immigrants to the United States are required to have their vaccinations updated as part of the mandatory medical screening prearrival. No such policy exists in Canada. The Public Health Agency of Canada recommends that health care providers who see immigrants assess and update immunizations and screen for chronic conditions that would alter vaccine recommendations $;{ }^{37}$ however, because of delays in health care coverage, difficulty in locating providers of primary care and competing priorities at the time of resettlement, these recommendations are often challenging to implement, and many new Canadians remain susceptible to some vaccine-preventable diseases.

Seroepidemiologic studies have also shown an increased burden of some vaccine-preventable diseases in Aboriginal communities. ${ }^{38-40}$ However, studies of this population have tended to use sera from specific communities ${ }^{37}$ or convenience samples ${ }^{39,40}$ with questionable generalizability to the diverse communities of First Nations, Métis and Inuit people. Ensuring the inclusion of both im- migrants and Aboriginal people in a future seroepidemiology program in Canada is both vitally important and challenging.

Other groups at risk are communities with low vaccination coverage due to vaccine refusal, such as communities that reject immunization based on religious beliefs or for philosophical reasons. $^{41-43}$ There have been outbreaks of vaccinepreventable diseases among underimmunized religious groups. ${ }^{44-48}$

\section{Evaluating vaccines}

After the introduction of new vaccines, seroepidemiology is an important adjunct to other methods of surveillance to monitor their long-term impact and duration of immunity, and to identify whether adjustments to vaccine policy are required.

Establishing serosurveillance programs has been instrumental to the successful control of measles in many countries where age-specific data on susceptibility to the disease has influenced vaccine policy. In the UK, the combination of seroepidemiologic data and mathematical modeling predicted the potential for a measles epidemic to occur by the mid-1990s..$^{49,50}$ This led to a national campaign in which $92 \%$ of children between the ages of 5 and 16 years were vaccinated. ${ }^{9}$ Subsequent serosurveys suggested that the campaign was a success, but they also showed high susceptibility among preschool-aged children. This informed the introduction of a second dose of MMR vaccine in the routine vaccination schedule at four years of age. ${ }^{9}$ Similarly, in Australia, seropreva-

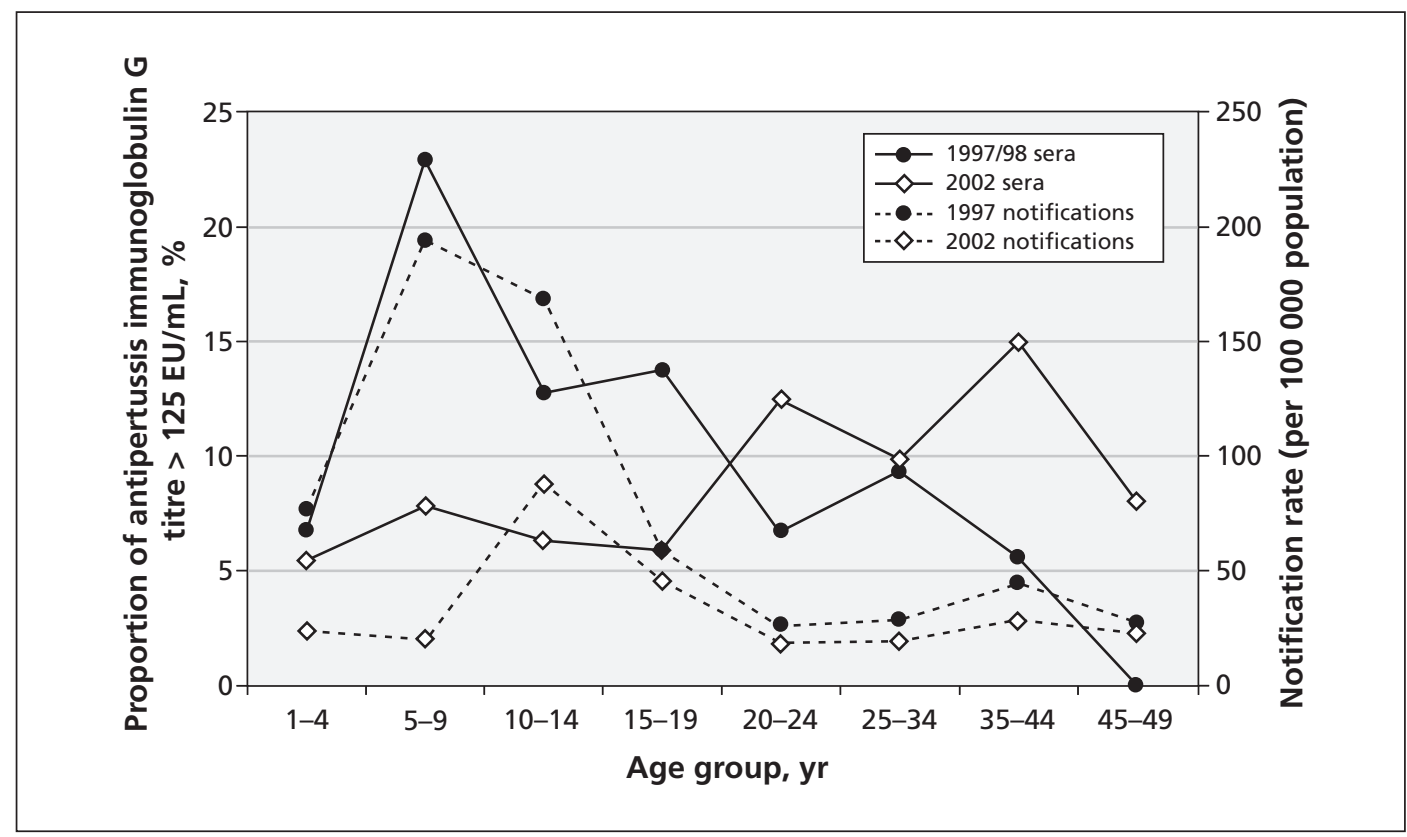

Figure 3: Age-specific trends in pertussis infection in Australia using both reportable disease notifications and population-based serosurveillance. From: Quinn HE, McIntyre PB, Backhouse JL, Gidding HF, Brotherton J, Gilbert GL. The utility of seroepidemiology for tracking trends in pertussis infection. Epidemiol Infect. 2010 Mar;138(3):426-33. ${ }^{28}$ Reprinted with the permission of Cambridge University Press. 
lence data identified young adults as having low levels of immunity to measles, and a targeted campaign of MMR vaccination began in 2001..$^{51,52}$

Serosurveillance has also been used to identify risks posed by emerging vaccine-preventable diseases in neighbouring regions. In response to a large outbreak of diphtheria in eastern Europe, a serosurvey of nearby countries found substantial proportions of adults with antitoxin titres below the putative protective threshold. This evidence suggested that few adults had been vaccinated despite changes to the vaccine policy that were implemented in response to the outbreak. ${ }^{53}$ High levels of protection among children and the limited infectiousness of diphtheria are thought to have protected these countries despite suboptimal protection among adults. ${ }^{53}$

\section{Modeling and health economic evaluations}

Seroepidemiologic data can be entered into mathematical models that can then be used to determine the potential for sustained outbreaks by calculating the effective reproductive number $\left(R_{\mathrm{e}}\right)$ for specific regions and/or age groups. This method has been used to predict the risk of future measles epidemics in both the UK and Australia, and it can also be used to estimate the costeffectiveness of vaccination programs and to predict their indirect consequences, such as increased age at infection and any attendant risks.

\section{Epidemiologic considerations for seroepidemiology programs}

There are two general approaches to serum sampling: convenience and population-based random sampling (Table 1). Most countries use "residual" sera submitted for diagnostic testing that would otherwise have been discarded (i.e., convenience sampling). Less commonly, countries collect sera from people randomly selected from a population-based sample. The advantages of population-based random sampling include the opportunity to obtain informed consent, to oversample specific groups and to obtain information at the level of the individual, including a person's history of vaccination. These advantages must be balanced against increased cost and the time required for population-based surveys.

Both methods present the risk of selection bias. For example, data from the Netherlands that used population-based random sampling found that the sole predictor of nonparticipation was individual perception of vaccines to be "unnecessary." ${ }^{15}$ Given that people with these beliefs are less likely to be vaccinated, seroepidemiologic programs using population-based sampling may overestimate population-level immunity to vaccine-preventable diseases. In contrast, use of residual sera may result in a bias toward populations with a higher number of medical comorbidities or different risk and health-seeking behaviours. Sera collected for occupational or prenatal screening could introduce healthyperson biases. The only published study comparing the two sampling approaches yielded similar estimates of immunity against five vaccinepreventable diseases at about a sevenfold increased cost for population-based sampling. ${ }^{55}$

\section{Challenges to implementation}

Developing a seroepidemiology network in Canada is ambitious and poses a number of challenges related to funding, ethics and epidemiologic and laboratory considerations. Detractors may cite these challenges as barriers to the implementation of a Canadian network; they may also argue that funding should be prioritized for new vaccine programs or for establishing other surveillance activities, such as a pan-Canadian immunization registry. However, these challenges are not insurmountable, and there will always be competing priorities for scarce resources. Establishing a seroepidemiology network would provide a strong evidence-informed foundation from which to successfully advocate for improvements in vaccine policy and methods of surveillance.

Funding and the longer-term stewardship of such a network is key to its successful implementation. Most seroepidemiologic studies in Canada have been supported by time-limited research funds. ${ }^{29,38,39,56,57}$ These studies show the epidemiologic and laboratory capacity to complete such work in Canada. Preliminary establishment of a network is likely to be started on a smaller scale in a limited number of participating provinces and territories, supported by research funds. However, in many jurisdictions, the seroepidemiology network is viewed as a core surveillance activity, as opposed to research, and receives dedicated government funding. The introduction of the Canadian Health Measures Survey, including plans for future surveys, affords the potential for using this federally funded initiative for the implementation of a Canadian seroepidemiology network.

If a de novo Canadian network were established, a number of practical and epidemiologic challenges would remain. The roles and responsibilities of provincial and federal stakeholders would require clarification. The selection of participating jurisdictions would ideally need to ensure representativeness of the Canadian popula- 
tion, including urban-rural composition, immigration trends and Aboriginal groups. Oversampling of specific at-risk groups may be required for accurate estimates of susceptibility to vaccinepreventable diseases, but this will likely require linkage to other sources of data, which may be viewed as a privacy issue in some quarters.

The collection of residual sera for analysis is the most pragmatic and least costly option for implementing a seroepidemiology network. However, this method raises important ethical and privacy issues that will need to be addressed, such as whether samples can be used without consent or notification, how anonymity can be ensured and whether record linking might be used. Precedence does exist - anonymized residual sera and record linking have been used in Canada without consent to assess the seroprevalence of HIV. ${ }^{58-61}$

Laboratory issues must also be addressed. Although provincial public health laboratories are the most appropriate facilities to coordinate testing, the extent to which their residual sera are representative of their province's general population may differ. Inclusion of hospital and commercial laboratories may be necessary. A second critical issue is that of standardization across laboratories and across manufacturers' assays. Immune correlates of protection do not exist for all vaccines, and cell-mediated immunity may be more important than humoral in some instances. In addition, the lack of sensitivity of some commercially available assays and limited access to commercially protected test methods makes assessing immunity to certain antigens challenging. A seroepidemiology network will also require capacity for longterm cryogenic storage at participating laboratories and supporting infrastructure that includes systems for inventory and the management and analysis of data. These challenges are not insurmountable, and there is a wealth of international experience in the establishment of national and international seroepidemiology networks from which Canada will benefit.

\section{Conclusion}

Canada is uniquely positioned to benefit from the establishment of a seroepidemiology network, with its strong evidence-based immunization policy, its range of immunization schedules, the diverse and growing proportion of new Canadians and strong supporting systems for the surveillance of vaccine-preventable diseases. The revision of the National Immunization Strategy currently underway may provide an opportunity to contribute to the establishment of a crucial, and currently missing, component of Canada's infrastructure for the surveillance of vaccinepreventable diseases.

\section{References}

1. Osborne K, Weinburg J, Miller E. The European seroepidemiology network. Euro Surveill 1997;2:29-31.

2. van Lier EA, Havelaar AH, Nanda A. The burden of infectious diseases in Europe: a pilot study. Euro Surveill 2007;12:E3-E4.

3. Health Protection Agency. Objectives of the European seroepidemiology network 2 (ESEN2). London (UK): The Agency; 2008. Available: www.hpa.org.uk/AboutTheHPA/WhatThe HealthProtectionAgencyDoes/InternationalWork/EuropeanSero EpidemiologyNetwork2ESEN2/interEsen2Objectives (accessed 2010 Dec. 20).

4. Jardine A, Deeks SL, Patel MS, et al. An evaluation of the Australian National Serosurveillance Program. Commun Dis Intell 2010;34:29-36

5. U.S. Department of Health, Education and Welfare. Plan and Operation of the Health and Nutrition Examination Survey United States - 1971-1973. Washington (DC): The Department; 1973. Available: www.cdc.gov/nchs/data/series/sr_01/sr01_010a pdf (accessed 2010 Dec.15)

6. Gidding H. Australia's national serosurveillance program. N S W Public Health Bull 2003;14:90-3.

7. De Melker HE, Conyn-van Spaendonck MA. Immunosurveillance and the evaluation of national immunization programmes: a population-based approach. Epidemiol Infect 1998; 121:637-43.

8. van der Klis FR, Mollema L, Berbers GA, et al. Second national serum bank for population-based seroprevalence studies in the Netherlands. Neth J Med 2009;67:301-8.

9. Osborne K, Gay N, Hesketh L, et al. Ten years of serological surveillance in England and Wales: methods, results, implications and action. Int J Epidemiol 2000;29:362-8.

10. Centers for Disease Control and Prevention. National health and nutrition examination survey, 2007-2008 overview. Atlanta (GA): The Centre; 2007. Available: www.cdc.gov/nchs/data/nhanes Inhanes 07 08/overviewbrochure 0708.pdf (accessed 2011 July 5).

11. Centers for Disease Control and Prevention. National health and nutrition examination survey 1999-2010 survey content. Atlanta (GA): The Centre; 2010. Available: www.cdc.gov/nchs/data /nhanes/survey_content_99_10.pdf (accessed 2011 July 5).

12. Gidding HF, Brisson M, Macintyre CR, et al. Modeling the impact of vaccination on the epidemiology of varicella zoster virus in Australia. Aust N Z J Public Health 2005;29:544-51.

13. Campbell H, Borrow R, Salisbury D, et al. Meningococcal C conjugate vaccine: the experience in England and Wales. Vaccine 2009;27:B20-9.

14. Centers for Disease Control and Prevention. NHANES contributions to public health. Atlanta (GA): The Centre. Available: www.cdc gov/nchs/video/nhanes50th_contributions/nhanes_contributions .pdf (accessed 2011 July 13)

15. Markowitz LE, Dunne EF, Saraiya M, et al. Quadrivalent human papillomavirus vaccine: recommendations of the Advisory Committee on Immunization Practices (ACIP). MMWR Recomm Rep 2007;56(RR-2):1-24.

16. Tremblay M, Wolfson M, Connor Gorber S. Canadian Health Measures Survey: rationale, background and overview. Ottawa (ON): Statistics Canada; 2007. Cat. no. 82-003-S. Available: www.statcan.gc.ca/pub/82-003-s/2007000/article/10361-eng.pdf (accessed 2010 Nov. 3).

17. Canadian Health Measures Survey: Cycle 1. Prevalence of hepatitis A antibody within the household population, by age and sex, Canada, 2007 to 2009 [Table 56 in Data Tables 2007 to 2009]. Ottawa (ON): Statistics Canada; 2009. Cat. no. 82-623-X. Available: www.statcan.gc.ca/pub/82-623-x/2010002/t060-eng .htm (accessed 2010 Dec. 30).

18. Canadian Health Measures Survey: Cycle 1. Prevalence of hepatitis A antibody within the household population, by age and sex, Canada, 2007 to 2009 [Table 57 in Data Tables 2007 to 2009]. Ottawa (ON): Statistics Canada; 2009. Cat. no. 82-623-X. Available: www.statcan.gc.ca/pub/82-623-x/2010002/t061-eng .pdf (accessed 2010 Dec. 30).

19. Canada facts and figures: immigrant overview permanent and temporary residents. Ottawa (ON): Citizenship and Immigration Canada; 2010. Available: www.cic.gc.ca/english/pdf/research-stats /facts2009.pdf (accessed 2010 Nov. 2)

20. 2006 Census: Immigration in Canada: a portrait of the foreignborn population, 2006 census findings. Ottawa (ON): Statistics Canada; 2007. Cat. no. 97-557-XIE. Available: www12.statcan.ca /census-recensement/2006/as-sa/97-557/pdf/97-557-XIE2006001 .pdf (accessed 2010 Nov. 2). 
21. Greenaway C, Dongier P, Boivin JF, et al. Susceptibility to measles, mumps, and rubella in newly arrived adult immigrants and refugees. Ann Intern Med 2007;146:20-4.

22. World Health Organization. Immunization assessment surveillance and monitoring. Rubella and congenital rubella syndrome (CRS). Available: www.who.int/immunization monitoring /diseases/rubella/en/index.html (accessed 2011 Aug. 26).

23. World Health Organization. Immunization assessment surveillance and monitoring. Rubella and congenital rubella syndrome (CRS). Available: www.who.int/immunization_monitoring /diseases/mumps_map_schedule.jpg (accessed 2011 Aug. 26).

24. National Advisory Committee on Immunization. Update on the use of conjugate pneumococcal vaccines in childhood. CCDR 2010:36;ACS-12. Available: www.phac-aspc.gc.ca/publicat/ccdr -rmtc/10vol36/acs-12/acs-12-eng.pdf (accessed 2010 Dec. 13).

25. Menzies R, McIntyre P. Vaccine preventable diseases and vaccination policy for indigenous populations. Epidemiol Rev 2006; 28:71-80

26. Erickson LJ, De Wals P, Farand L. An analytical framework for immunization programs in Canada. Vaccine 2005;23:2470-6.

27. de Greeff SC, de Melker HE, van Gageldonk PG, et al. Seroprevalence of pertussis in the Netherlands: evidence for increased circulation of bordetella pertussis. PLOS ONE 2010;5:e14183.

28. Quinn HE, McIntyre PB, Backhouse JL, et al. The utility of seroepidemiology for tracking trends in pertussis infection. Epidemiol Infect 2010;138:426-33.

29. Achonu C. A seroprevalence study of pandemic influenza A H1N1 among Ontarians. Proceedings of the Centennial Canadian Public Health Association Conference; 2010 June 13-16; Toronto (ON).

30. Miller E, Hoschler K, Hardelid P, et al. Incidence of 2009 pandemic influenza A H1N1 infection in England: a cross-sectional serological study. Lancet 2010;375:1100-8

31. Gilbert GL, Cretikos MA, Hueston L, et al. H1N1) 2009 antibodies in residents of New South Wales, Australia, after the first pandemic wave in the 2009 southern hemisphere winter. PLoS ONE 2010;5:e12562.

32. Barnett ED, Christiansen D, Figueira M. Seroprevalence of measles, rubella, and varicella in refugees. Clin Infect Dis 2002; 35:403-8

33. Talukder YS, Kafatos G, Pinot de Moira A, et al. The seroepidemiology of varicella zoster virus among pregnant Bangladeshi and white British women in the London Borough of Tower Hamlets, UK. Epidemiol Infect 2007;135:1344-53.

34. Rubella among hispanic adults - Kansas, 1998, and Nebraska, 1999. MMWR Morb Mortal Wkly Rep 2000;49:225-8 Available: www.cdc.gov/mmwr/preview/mmwrhtml/mm4911a1.htm (accessed 2010 Dec. 15)

35. Control and prevention of rubella: evaluation and management of suspected outbreaks, rubella in pregnant women, and surveillance for congenital rubella syndrome. MMWR Morb Mortal Wkly Rep 2001;50(RR12):1-23. Available: www.cdc.gov/mmwr /preview/mmwrhtml/rr5012a1.htm (accessed 2010 Dec. 15).

36. Lemos C, Ramirez R, Ordobas M, et al. New features of rubella in Spain: the evidence of an outbreak. Euro Surveill 2004;9:9-11.

37. Public Health Agency of Canada. Recommended immunization, immunization of persons new to Canada, Canadian immunization guide 2006. Ottawa (ON): The Agency; 2007. Available: www.phac-aspc.gc.ca/publicat/cig-gci/p03-11-eng.php (accessed 2010 Dec. 13).

38. Minuk GY, Uhanova J. Viral hepatitis in the Canadian Inuit and First Nations populations. Can J Gastroenterol 2003;17:707-12.

39. Martin JD, Mathias RG, Sarin C, et al. HIV and hepatitis B surveillance in First Nations alcohol and drug treatment centres in British Columbia, Canada, 1992-2000. Int J Circumpolar Health 2002;61:104-9.

40. Martin JD, Mathias RG, Sarin C, et al. Human T-lymphotropic virus type I and II infections in First Nations alcohol and drug treatment centres in British Columbia, Canada, 1992-2000. Int J Circumpolar Health 2002;61:98-103.

41. Rujis WL, Hautvast JL, van der Velden K, et al. Religious subgroups influencing vaccine coverage in the dutch bible belt: an ecological study. BMC Public Health 2011;11:102.

42. Kulig JC, Meyer CJ, Hill SA et al. Refusals and delay of immunization within southwest Alberta. Understanding alternative beliefs and religious perspectives. Can J Public Health 2002; 93:109.

43. Smith PJ, Chu SY, Barker LE. Children who have received no vaccines: Who are they and where do they live? Pediatrics 2004; 114:187-95.
44. Hahne S, Macey J, van Binnendijk R, et al. Rubella outbreak in the Netherlands, 2004-2005: high burden of congenital infection and spread to Canada. Pediatr Infect Dis J 2009:28;795-800

45. Morris W, Bennetch JM, Zell ER, et al. Measles among the Amish: a comparative study of measles severity in primary and secondary cases in households. J Infect Dis 1991;163:12-6.

46. Tan KE, Anderson M, Krajden M, Petric M. Mumps detection during an outbreak in a highly unvaccinated population in British Columbia. Can J Public Health 2011;102:47-50.

47. Briss P, Fehrs LJ, Hutcheson RH, Schaffner W. Rubella among the Amish: resurgent disease in a highly susceptible community. Pediatr Infect Dis J 1992;11:955-9.

48. Eggers $\mathrm{P}$, Austin D, Hathcock $\mathrm{P}$ et al. Pertussis outbreak in an Amish community-Kent County, Delware, September 2004February 2005. MMWR 2006;55:817-21.

49. Ramsay M, Gay N, Miller E, et al. The epidemiology of measles in England and Wales: rationale for the 1994 national vaccination campaign. Commun Dis Rep CDR Rev 1994;4:R141-6.

50. Gay NJ, Hesketh LM, Morgan-Capner P, et al. Interpretation of serological surveillance data for measles using mathematical models: implications for vaccine strategy. Epidemiol Infect 1995; $115: 139-56$

51. Gilbert GL, Escott RG, Gidding HF, et al. Impact of the Australian Measles Control Campaign on immunity to measles and rubella. Epidemiol Infect 2001;127:297-303.

52. Campbell M. Young adult measles vaccination [editorial]. Commun Dis Intell 2000;24:241-2

53. Edmunds WJ, Pebody RG, Aggerback H, et al. The seroepidemiology of diphtheria in western Europe. ESEN Project. European Sero-Epidemiology Network. Epidemiol Infect 2000; 125:113-25.

54. De Melker HE, Nagelkerde NJ, Conyn-van Spaendonck MA Non-participation in a population-based seroprevalence study of vaccine-preventable diseases. Epidemiol Infect 2000;124:255-62.

55. Kelly H, Riddell MA, Gidding HF, et al. A random cluster survey and a convenience sample give comparable estimates of immunity to vaccine preventable diseases in children of school age in Victoria, Australia. Vaccine 2002;20:3130-6.

56. Duval B, De Serres G, Ochnio J, et al. Nationwide Canadian study of hepatitis a antibody prevalence among children eight to thirteen years old. Pediatr Infect Dis J 2005;24:514-9.

57. Scheifele DW, De Serres G, Gilca V, et al. A nationwide survey of past hepatitis A infections among Canadian adults. Vaccine 2010;28:5174-8

58. Sherlock $\mathrm{CH}$, Strathdee SA, Le T, et al. Use of pooling and outpatient laboratory specimens in an anonymous seroprevalence survey of HIV infection in British Columbia, Canada. AIDS 1995;9:945-50.

59. Remis RS, Eason EL, Palmer RW, et al. HIV infection among women undergoing abortion in Montreal. CMAJ 1995;153:1271-9.

60. Alary M, Joly JR, Parent R, et al. Sentinel hospital surveillance of HIV infection in Quebec. Quebec Sentinel Hospital HIVSeroprevalence Study Group. CMAJ 1994;151:975-81.

61. Plitt SS, Singh AE, Lee BE, et al. HIV seroprevalence among women opting out of prenatal HIV screening in Alberta, Canada: 2002-2004. Clin Infect Dis 2007;45:1640-3.

Affiliations: From the Canadian Field Epidemiology Program (Wilson), Public Health Agency of Canada, Ottawa, Ont.; Public Health Ontario (Wilson, Deeks, Crowcroft); the Dalla School of Public Health (Wilson, Deeks, Crowcroft), University of Toronto, Toronto, Ont.; and the Department of Pathology and Laboratory Medicine (Hatchette), Dalhousie University, Halifax, NS

Contributors: Natasha Crowcroft developed the concept for the article. Sarah Wilson drafted the article. All of the authors critically revised the manuscript for important intellectual content and approved the final version submitted for publication.

Acknowledgement: The authors thank the participants of a meeting funded by the Canadian Institutes of Health Research convened to discuss Canadian research priorities in the field of seroepidemiology (Oct. 13-14 2011).

Note: The opinions expressed in this paper are those of the authors and do not necessarily represent the position of the Public Health Agency of Canada. 